\title{
PROPOSAL OF IN SITU PARAMETERS FOR THE ASSESSMENT OF PHYSICAL VULNERABILITY TO SEISMIC EVENTS: A PERUVIAN CASE STUDY
}

\author{
LUIS IZQUIERDO-HORNA \& ANDREA GALVÁN \\ Universidad Tecnológica del Perú, Perú
}

\begin{abstract}
After the last seismic event that occurred in Pisco, Peru in 2007 (7.9 Mw), the fragility of the structural conditions of the existing houses in the Peruvian territory became evident. Therefore, it is important to be able to anticipate or recognize those dwellings that are more physically vulnerable in order to preserve the livelihoods and living conditions of the residents. In this sense, the instruments currently used for this purpose do not guarantee an adequate assessment of reality. Thus, the objective of this research is to propose a set of parameters to determine the level of physical vulnerability present for a given sector based on its structural and constructive characteristics. For this purpose, it was necessary to determine the structural typology of the sector based on the predominant material, number of floors, structural damage and the construction process stage. This information will allow the selection of a set of parameters potentially capable of adequately identifying the level of physical vulnerability in the dwelling. The district of Los Olivos was chosen as a case study. This research resulted in a set of parameters grouped into the following categories: construction system, irregularity and soil condition, roofing system, structural interaction and state of conservation. These categories and their descriptors are applicable and reproducible at different territorial scales.
\end{abstract}

Keywords: physical vulnerability, in situ parameters, earthquakes, risk and disaster management.

\section{INTRODUCTION}

Over the years, the multiple earthquakes that have occurred in Latin America have had a huge impact on the gross domestic product (GDP) [1]. For example, in 2007 there was an earthquake in Pisco with a magnitude equal to $7.9 \mathrm{Mw}$, which destroyed, disabled and affected 48,208, 45,500 and 45,813 homes, respectively, and seriously affected 14 health facilities [2], resulting in an economic impact of more than 139 million dollars [3]. These consequences can be explained through the poor awareness of the inhabitants and the high vulnerability of the built environment [4]. Therefore, in order to reduce the effects caused by this type of phenomena of natural origin, it is necessary to have a tool that allows an adequate identification of the conditions of the present houses in order to mitigate the seismic risk [5].

On the other hand, considering seismic risk as the possibility of altering a system, product of the interaction of hazard and vulnerability of the same system [6], this research will focus on analyzing this last component because it is determined by man [7]. Although, the vulnerability component can be studied in multiple dimensions (i.e., social, economic, environmental, etc.) [8], this research will focus on analyzing the physical component of vulnerability. This dimension will focus on analyzing the built environment of the end user, through in situ parameters and event characteristics [9]. The lack of attention to this dimension could be observed after the earthquake in Chile $(6.5 \mathrm{Mw})$, where the different damages suffered by buildings that shared similar characteristics were evident [10]. Given this diversity of effects, it is necessary to design an assessment instrument that allows a comparative recognition between buildings within the same urbanization, allowing the proposal of useful measures that can reduce the seismic risk of the same [11], [12]. 
With this in mind, Ordaz et al. [1] proposed assessing the physical vulnerability of the buildings in Toluca based on three parameters (i.e., type of material and construction design, age of the buildings and construction period) resulting in that 1,430 and 866 dwellings presented, respectively, a high and very high vulnerability showing an adequate classification, even when general and applicable parameters were considered as long as the area of interest is made up of correctly constructed structures. Under this same approach, in Venezuela, López et al. [11] considered 6 parameters that emphasized the differences between buildings within the study area (i.e., regulations, building age, irregularity, structural type, degree of deterioration, drainage, topography and depth of the deposit) to carry out an earthquake response prioritization study. On the other hand, Zora and Acevedo [13] propose to consider some additional parameters so that their results can demonstrate the conditions of the area, such as the existence of short columns, number of longitudinal axes in plan, year of construction, etc.

With the aim of achieving a simple and effective assessment, methods such as the Benedetti-Petrini or commonly called the vulnerability index emerged, which incorporates parameters that facilitate the inspection of each home [14]. Gent et al. [10] improved this methodology by applying it to Chilean confined masonry constructions, adding as a parameter the occurrence of an earthquake of magnitude equal to or greater than that of 1985 . Similarly, Maldonado and Chio [12] adapted the method based on the characteristics of the sector (i.e., slope and topography). Similarly, Ortega et al. [15] combined the BenedettiPetrini method with expert judgment and static modeling. Similarly, researchers like Formisano et al. [16], Kassem et al. [17], Chieffo et al. [18], Mosoarca et al. [19], [20], and Kappes et al. [21] updated the Benedetti-Petrini method considering the construction not only individually, but also as part of a whole. Therefore, parameters such as: structural heterogeneity, elevation interaction, number of staggered floors, building position and percentage difference in opening areas between adjacent facades were added.

For all the aforementioned, it should be emphasized that, even when the uncertainty or randomness of the parameters and phenomenon of natural origin is not considered [22], assessing structural vulnerability based on parameters is very useful, since it is considered within them, the most determining characteristics that influence the physical vulnerability of the construction to a seismic event [23]. Thus, this research will focus on developing a proposal for in situ parameters that allow determining the level of physical vulnerability in the study area with the greatest possible precision. Section 2 will describe the methods used. In addition, relevant information about the study field is also presented. The results will be described in Section 3 and discussed in Section 4. Finally, Section 5 shows our conclusions.

\section{METHODOLOGY}

Within the different methodological proposals to determine the level of physical vulnerability, the parameters used were chosen based on the opinion of experts regarding the factors that influence a construction [24]. However, in order to have an adequate assessment, it is important to know not only the available literature, but also the case study. In this sense, the A.H. (Human Settlement) Laura Caller - Los Olivos was chosen as an area of interest. Thus, from the analysis of the most prominent and characteristic parameters of physical vulnerability in homes, those that directly influence the area of interest will be identified. For this, through the virtual tour on Google Maps, the classification and description of the structural typology in the study area was obtained. Then, with the data previously obtained in conjunction with the literary review, the selection of the set of parameters that influence and classify the level of physical vulnerability among housing constructions is made. Fig. 1 summarizes the methodological proposal. 
PROPOSAL OF IN SITU PARAMETERS FOR THE ASSESSMENT OF PHYSICAL VULNERABILITY TO SEISMIC EVENTS: A PERUVIAN CASE STUDY

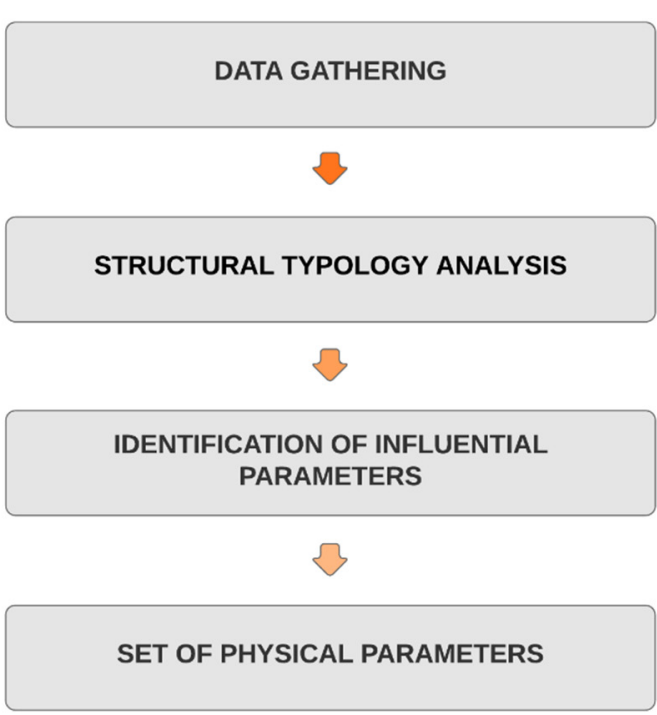

FIELD WORK

NATIONAL REPORTS

LOCAL REPORTS

Figure 1: Methodological framework.

\subsection{Description of the study area}

The district of Los Olivos (Lima, Peru) has a territorial extension of $18.25 \mathrm{~km}^{2}$, located at the coordinates $11^{\circ} 58^{\prime} 13^{\prime \prime}$ of South latitude and $77^{\circ} 04^{\prime} 26^{\prime \prime}$ of West longitude [25]. According to data registered from the last national census, the population is 325,884 inhabitants, of which $51.87 \%$ were women and $48.13 \%$ were men; likewise, registering a total of 82,848 dwellings [26]. Despite being a recently created district in Lima, it has optimal levels of employability, health and education, exceeding the percentage average compared to other districts [27]. The seismic hazard that Los Olivos will have to face is governed by its location on the coast of Peru, where different earthquakes occurred in the last 5 centuries, highlighting - among them - those that occurred in 1746, 1966 and 1974 with magnitudes of $9 \mathrm{Mw}, 7.5 \mathrm{Mw}$ and $8 \mathrm{Mw}$, respectively [2]. Therefore, the A.H. Laura Caller will be used as a sample to identify the parameters of physical vulnerability. Fig. 2 shows the location of the case study.

\subsection{Determination of the structural typology}

The damage that a building can suffer after a seismic movement is linked to the type of material used, the building design and the location where its execution was carried out, since the damage manifested will never be the same if we analyze and compare a masonry construction (regardless of whether it is with or without confinement) with one of adobe, considering both as correctly made constructions [1]. Now, if in these a structural component had been omitted or a construction stage was performed poorly, it would not be so easy to 


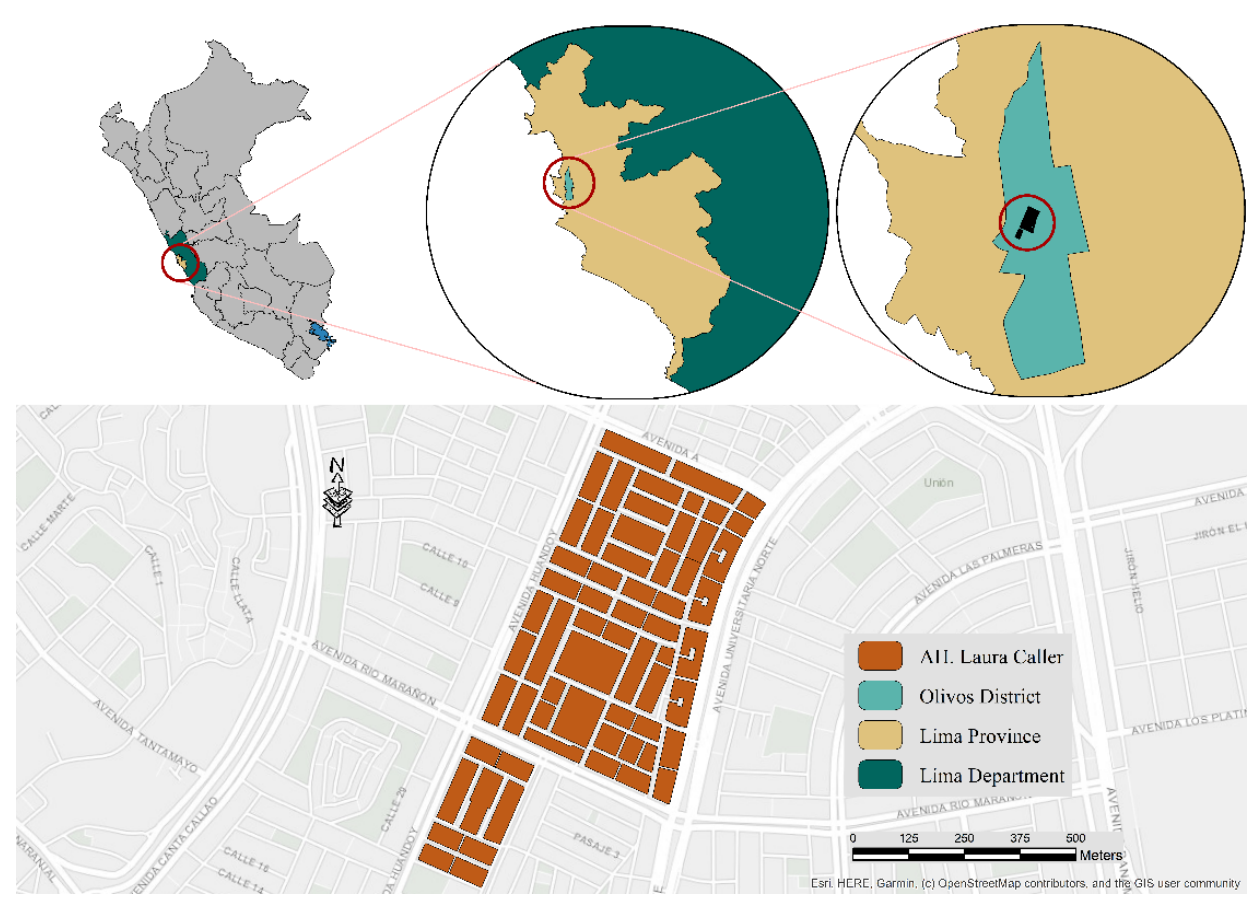

Figure 2: Location map of the A.H. Laura Caller.

indicate which construction would be most affected. Considering the above, the identification of the structural typology of the study area was developed through recognition, first of the study area, through the cadastre of the area in dwg format (AutoCAD program), listing the blocks within the chosen sector and establishing the number of dwellings that comprise it. This first tour was complemented with a virtual tour (through Google Maps). Then, after viewing each home and parameters such as: predominant material, number of floors, current wear and tear, and stage of the construction process, it was possible to define 4 different types. Table 2 , in the results section, shows the structural typology of the dwellings analyzed in the case study.

\subsection{Identification of the most influential parameters}

The compilation of the parameters that contributed as input in different methodologies was previously used, grouping them into three categories, which will be corroborated by existing research and related to the study area. The first component is the location and condition of the soil, since - according to the type of material and the properties that are present - can increase the seismic force that influences the construction [28]. The second component will be the type of structural system, since, according to the material used, the conditions or construction standards that should have been considered based on it are established [29]. The third and last component is the number of floors, which is conditioned to the first two components [30]. With this preliminary information, a set of parameters related to the area of interest is outlined. For this, concepts for each one are established in order to avoid duplication of measurement and scope of the same parameter. In order to simplify and achieve an adequate understanding, it was decided to group in five categories i.e., structural 
construction system, irregularities and condition of the soil, floors and roofs, state of conservation and non-structural elements and as the fifth and last category, structural interaction. Table 1 shows the preliminary classification grouped into the categories shown above.

Table 1: Classification of parameters in relation to categories.

\begin{tabular}{|c|c|c|c|}
\hline Category & Item & Parameter & $\begin{array}{l}\text { Previous } \\
\text { studies }\end{array}$ \\
\hline \multirow{4}{*}{$\begin{array}{l}\text { Structural } \\
\text { construction } \\
\text { system }\end{array}$} & $\mathrm{P} 1$ & Resilient system organization & [21], [23] \\
\hline & $\mathrm{P} 2$ & Quality of the resilience system & {$[11],[23]$} \\
\hline & P3 & Conventional resilience & [23], [29] \\
\hline & $\mathrm{P} 4$ & Maximum walls distance & {$[11],[15],[19]$} \\
\hline \multirow{3}{*}{$\begin{array}{l}\text { Irregularities and } \\
\text { soil condition }\end{array}$} & P5 & Added position and interaction & {$[31],[32]$} \\
\hline & P6 & Plant configuration & {$[4],[11]$} \\
\hline & $\mathrm{P} 7$ & Height regularity & {$[5],[17]$} \\
\hline \multirow{3}{*}{ Slabs and roofs } & P8 & Slab facade openings & {$[4],[31]$} \\
\hline & P9 & Horizontal diaphragms & [17], [29] \\
\hline & $\mathrm{P} 10$ & Roofing system & {$[17],[29]$} \\
\hline \multirow{2}{*}{$\begin{array}{l}\text { Conservation state } \\
\text { and other elements }\end{array}$} & P11 & Fragility and state of conservation & {$[4],[13]$} \\
\hline & $\mathrm{P} 12$ & Non-structural elements & {$[23],[31]$} \\
\hline \multirow{5}{*}{$\begin{array}{l}\text { Structural } \\
\text { interaction }\end{array}$} & $\mathrm{P} 13$ & Height difference & {$[5],[16],[33]$} \\
\hline & P14 & Position within a block & {$[5],[10],[16]$} \\
\hline & $\mathrm{P} 15$ & Number of staggered floors & {$[5],[16]$} \\
\hline & $\mathrm{P} 16$ & Structural heterogeneity & {$[16],[17]$} \\
\hline & $\mathrm{P} 17$ & $\begin{array}{l}\text { Difference of the opening area } \\
\text { percentage }\end{array}$ & {$[15],[16]$} \\
\hline
\end{tabular}

On the other hand, considering that it is desired to achieve an adequate differentiation and classification of the level of physical vulnerability of the dwellings, the parameters were analyzed and selected based on two criteria based on the preliminary collection of parameters and the structural typology of the study area. These selection criteria consist in avoiding that the selected parameter is present or absent in the same way or measure in all the dwellings and also in considering a parameter even when it is little present.

\section{RESULTS}

Regarding the first component related to the location and condition of the soil, the Japanese Peruvian Center for Seismic Research and Disaster Mitigation (CISMID) determined that the Los Olivos district found that the soils present favorable characteristics for the foundation of buildings [34]. In addition, local reports maintain that the topography is flat throughout the territory except for two areas with a slope greater than $45 \%$ [25]. In accordance with the second component, the analysis of the structural typology resulted in that $25.3 \%$ of the houses 
analyzed are made of adobe, which had covered with corrugated sheets or mats, likewise, of $73.2 \%$ of the houses analyzed are made of masonry, with no roof, indicating that the construction was paralyzed in the last level, and in case of having them, these were either of reinforced concrete or sheets of corrugated iron. Table 2 shows in detail the configuration of the 4 types of structural typology identified in the study area. Finally, in relation to the third and last component, which is the number of flats, in the area the existence of one-story homes was recorded by $4 \%$, two-story homes by $11 \%$, and three-story homes by $17 \%$. Those with four floors were $25 \%$ and for those with 5 floors $42 \%$, which are randomly distributed in the sector. Considering the information described for the 3 components with respect to the study area, the parameters that would be most useful and help to identify and classify the level of physical vulnerability of the dwellings are presented in Table 3.

Table 2: Structural typology of the study area.

\begin{tabular}{ll}
\hline Type & \multicolumn{1}{c}{ Characteristics } \\
\hline A & $\begin{array}{l}\text { One-story adobe buildings, without any type of confinement, with a light roof } \\
\text { such as calamine, simply leaned-on, showing wear at the base due to humidity. }\end{array}$ \\
\hline B & Masonry buildings completed, finding in the study area up to 5 floors. \\
\hline C & $\begin{array}{l}\text { Masonry buildings of up to } 5 \text { levels, with a corrugated sheet or mat roof, placed } \\
\text { and nailed on circular timbers placed throughout the roofing area (ranging from } \\
\text { ends between two parallel perimeter walls) at random distances, independent of } \\
\text { the presence of the perimeter beam. }\end{array}$ \\
\hline D & $\begin{array}{l}\text { Unfinished masonry buildings of } 1 \text { to } 4 \text { levels, observing the state of } \\
\text { abandonment due to the presence of oxidation of the protruding or exposed } \\
\text { steels, absence of columns in some of the cases or presence of walls at an } \\
\text { intermediate level, indicating that the continuation of said construction will be } \\
\text { carried out according to the economic disposition at home. }\end{array}$ \\
\hline
\end{tabular}

\section{DISCUSSION}

From the typological analysis carried out, it is important to consider that approximately $25 \%$ of the analyzed houses were built based on adobe (type A), generating a disadvantage in terms of resilience compared to the other types identified. Part of this housing conformation can be explained through social or economic factors [35]. Regarding the categories of preliminary parameters, the structural construction system is one of the most important because they contemplate common failures within a construction - whether it is self-built or not - , since it is not the same to evaluate a construction with the presence of a basement with those that present only higher levels. On the other hand, one of the most important parameters is the type of soil, which can cause very serious problems such as what happened in 2017 in Tehuantepec, Mexico [32]. However, it is not representative for the study area, since in small sectors such as the one taken into consideration, where the geotechnical and typological composition do not vary, still being one of the optimal ones, it would not be a differential of physical vulnerability between the dwellings. The district has two small sectors with a slope greater than $45 \%$, nevertheless. Likewise, the roof parameter is one of the most important and neglected ones in the study area, proof of this is the existence of type $\mathrm{D}$ and $\mathrm{C}$ dwellings, which will not present homogeneous displacement in all their structures, damaging the elements and adjacent buildings. 
Table 3: Final parameter set.

\begin{tabular}{|c|c|c|}
\hline Parameter & Contribution & Optimal condition \\
\hline $\begin{array}{l}\text { Resilient system } \\
\text { organization }\end{array}$ & $\begin{array}{l}\text { Avoid diagonal fracturing of } \\
\text { the walls through the presence } \\
\text { of confinement. }\end{array}$ & $\begin{array}{l}\text { Confinement of the walls on its four } \\
\text { sides. }\end{array}$ \\
\hline $\begin{array}{l}\text { Quality of the } \\
\text { resilient system }\end{array}$ & $\begin{array}{l}\text { Confinement according to the } \\
\text { material to avoid the } \\
\text { detachment of any element. }\end{array}$ & $\begin{array}{l}\text { Respecting the verticality and thickness } \\
\text { of the mortar, which must be } \\
\text { homogeneous. }\end{array}$ \\
\hline $\begin{array}{l}\text { Conventional } \\
\text { resilience }\end{array}$ & $\begin{array}{l}\text { Capacity to support external } \\
\text { forces, whether seismic or } \\
\text { produced by the environment. }\end{array}$ & $\begin{array}{l}\text { The density of the walls between the } \\
\text { horizontal force should be less than } 1 \text {. }\end{array}$ \\
\hline $\begin{array}{l}\text { Maximum walls } \\
\text { distance }\end{array}$ & $\begin{array}{l}\text { Achieve confinement to the } \\
\text { greatest extent possible. }\end{array}$ & $\begin{array}{l}\text { For masonry, the cavity of the wall must } \\
\text { not exceed twice the height of the wall; in } \\
\text { the case of adobe, it depends on the } \\
\text { thickness of the wall used. }\end{array}$ \\
\hline Height regularity & $\begin{array}{l}\text { The transmission of the } \\
\text { seismic force occurs from the } \\
\text { upper floor to the lower one } \\
\text { cumulatively. }\end{array}$ & $\begin{array}{l}\text { Ideally, each home has homogeneous } \\
\text { levels or variation that does not modify } \\
\text { the resistance dramatically. }\end{array}$ \\
\hline $\begin{array}{l}\text { Slab facade } \\
\text { openings }\end{array}$ & $\begin{array}{l}\text { The resistance of the slab will } \\
\text { be weakened by the presence } \\
\text { of internal voids from where } \\
\text { the different failures will } \\
\text { occur. }\end{array}$ & $\begin{array}{l}\text { Ideally, it should not have voids and, if } \\
\text { they do, it should be confined around the } \\
\text { perimeter of the void. }\end{array}$ \\
\hline $\begin{array}{l}\text { Horizontal } \\
\text { diaphragms }\end{array}$ & $\begin{array}{l}\text { Achieve displacement } \\
\text { homogeneity in full seismic } \\
\text { activity. }\end{array}$ & $\begin{array}{l}\text { Embedment in the beams and correctly } \\
\text { supported by columns. }\end{array}$ \\
\hline Roofing system & Material and quality. & It should not show bending or damage. \\
\hline $\begin{array}{l}\text { Fragility and state } \\
\text { of conservation }\end{array}$ & $\begin{array}{l}\text { The damage that the } \\
\text { construction may present } \\
\text { causing the resistance itself to } \\
\text { be weakened. }\end{array}$ & $\begin{array}{l}\text { It must not have cracks or wear in the } \\
\text { structural elements. }\end{array}$ \\
\hline $\begin{array}{l}\text { Non-structural } \\
\text { elements }\end{array}$ & $\begin{array}{l}\text { Elements that, although they } \\
\text { do not provide resistance to } \\
\text { the construction system, can } \\
\text { generate damage to the } \\
\text { inhabitants. }\end{array}$ & $\begin{array}{l}\text { Must be correctly placed, avoiding } \\
\text { detachment. }\end{array}$ \\
\hline Height difference & $\begin{array}{l}\text { The mezzanine of the } \\
\text { adjacent building would hit } \\
\text { the wall, causing it to have to } \\
\text { withstand a greater horizontal } \\
\text { force. }\end{array}$ & $\begin{array}{l}\text { All must be at the same level, since the } \\
\text { additional force would fall between the } \\
\text { slabs that will be in charge of distributing } \\
\text { said force. }\end{array}$ \\
\hline $\begin{array}{l}\text { Position within a } \\
\text { block }\end{array}$ & $\begin{array}{l}\text { Location of the lot within the } \\
\text { block, being able to be } \\
\text { located on a corner or } \\
\text { between two lots. }\end{array}$ & $\begin{array}{l}\text { Be located in the middle of two lots, as } \\
\text { the movement can be expected to be } \\
\text { homogeneous. }\end{array}$ \\
\hline $\begin{array}{l}\text { Number of } \\
\text { staggered floors }\end{array}$ & $\begin{array}{l}\text { Regarding the heights of both } \\
\text { the house to be analyzed and } \\
\text { that of its adjacent ones. }\end{array}$ & Find yourself on the same level. \\
\hline $\begin{array}{l}\text { Difference of the } \\
\text { opening area } \\
\text { percentage }\end{array}$ & $\begin{array}{l}\text { Proportion of voids in the } \\
\text { walls between adjoining } \\
\text { buildings. }\end{array}$ & $\begin{array}{l}\text { In general terms, it is necessary to try to } \\
\text { have the lowest percentage of voids, since } \\
\text { this weakens the resistance of the wall. }\end{array}$ \\
\hline
\end{tabular}




\section{CONCLUSIONS}

In summary, a methodology has been presented to determine a set of parameters based on the typology of the study area, which conditions the assessment of the physical vulnerability of a dwelling. This proposed set of parameters is easy to understand and identify. With a view to later creating or adapting a methodology to identify the level of fiscal vulnerability of dwellings with a typology equal to that found in Los Olivos, the parameters that were presented can be used as input, leaving to each individual criteria, the degrees of vulnerability and the partial or total use of the selected indicators, achieving that the elaborated instrument can be easily implemented by people with basic construction knowledge, thereby achieving a reduction in time and costs, unlike the implementation of complex methodology where they require highly trained staff or other application techniques (i.e., machine learning).

\section{ACKNOWLEDGEMENTS}

The authors would like to thank Rubén Varillas and the Department of Civil Engineering of the Universidad Tecnológica del Perú for their valuable support in the process of publication and dissemination of this manuscript.

\section{REFERENCES}

[1] Ordaz, A., Hernández, J. \& Garatachia, J., Cartographic approach to structural vulnerability to earthquakes using a qualitative methodology: Application to the city of Toluca. Cuad Geográficos, 59, pp. 178-198, 2020.

DOI: $10.30827 /$ cuadgeo.v59i2.9340.

[2] sMorales-soto, N. \& Zavala, C., Earthquakes in the Central Coast of Peru: Could it be lima the scene of a future disaster? Revista Peruana de Medicina Experimental y Salud Pública, 25, pp. 217-224, 2008.

[3] Bambarén, C. \& Alatrista, M del S., Estimation of the socioeconomic impact of the Pisco earthquake on the Peruvian health sector. Revista Medica Herediana, 20, pp. 89, 2012. DOI: $10.20453 / \mathrm{rmh} . v 20 \mathrm{i} 2.988$.

[4] Khan, S., Qureshi, M., Rana, I. \& Maqsoom, A., An empirical relationship between seismic risk perception and physical vulnerability: A case study of Malakand, Pakistan. International Journal of Disaster Risk Reduction, 41, pp. 1-9, 2019.

DOI: 10.1016/j.ijdrr.2019.101317.

[5] Guardiola-Víllora, A. \& Basset-Salom, L., Seismic risk scenarios for the Eixample district of the city of Valencia. Revista Internacional de Métodos Numéricos para Cálculo y Diseño en Ingeniería, 31, pp. 81-90, 2015.

DOI: 10.1016/j.rimni.2014.01.002.

[6] Ocola, L., Hazard, vulnerability, risk and the possibility of seismic disasters in Peru. Rev Geofisica, 61, pp. 60-125, 2005.

[7] Birkmann, J., Assesing vulnerability in the context of multiple-stressors. Vulnerability Assessment and Adaptation Planning, pp. 1-25, 2010.

[8] Wisner, B., Blaikie, P., Cannon, T. \& Davis, I., At risk. 43, 2003.

[9] Izquierdo-Horna, L. \& Kahhat, R., Methodological framework to integrate social and physical vulnerability in the prevention of seismic risk. Risk Analysis, 121, pp. 69-79, 2018. DOI: $10.2495 /$ RISK180061.

[10] Gent, K., Astroza, M. \& Giulano, G., IX Chilean Congress of Seismology and Earthquake Engineering IX Conference. Calibration GNDT Vulnerability Index to Chil. Build. Confin. Mason. Struct., pp. 1-15, 2005. 
[11] López, O., Coronel, G. \& Rojas, R., Prioritization indices for seismic risk management in existing buildings. Revista de la Facultad de Ingeniería Universidad Central de Venezuela, 29, pp. 107-126, 2014.

[12] Maldonado, E. \& Chio, G., Estimation of seismic vulnerability functions in earthen buildings. Ing y Desarro, 25, pp. 180-99, 2009.

[13] Zora, F. \& Acevedo, A., Seismic vulnerability index of schools of the metropolitan area of Medellin, Colombia. Environmental Impact Assessment Review, 16, pp. 195207, 2019. DOI: 10.24050/reia.v16i32.1035.

[14] Benedetti, D. \& Petrini, V., Sulla vulnerabilita sismica di edifici in muratura: un metodo di valutazione. A method for evaluating the seismic vulnerability of masonry buildings, 1984.

[15] Ortega, J., Vasconcelos, G., Rodrigues, H. \& Correia, M., A vulnerability index formulation for the seismic vulnerability assessment of vernacular architecture. Engineering Structures, 197, pp. 1-20, 2019. DOI: 10.1016/j.engstruct.2019.109381.

[16] Formisano, A., Florio, G., Landolfo, R. \& Mazzolani, F., Numerical calibration of an easy method for seismic behaviour assessment on large scale of masonry building aggregates. Advances in Engineering Software, 80, pp. 116-38, 2015.

DOI: 10.1016/j.advengsoft.2014.09.013.

[17] Kassem, M., Mohamed, F., \& Noroozinejad, E., Development of seismic vulnerability index methodology for reinforced concrete buildings based on nonlinear parametric analyses. MethodsX, 6: pp. 199-211, 2019. DOI: 10.1016/j.mex.2019.01.006.

[18] Chieffo, N., Clementi, F., Formisano, A. \& Lenci, S., Comparative fragility methods for seismic assessment of masonry buildings located in Muccia (Italy). Journal of Building Engineering, 25, pp. 1-14, 2019. DOI: 10.1016/j.jobe.2019.100813.

[19] Mosoarca, M., Onescu, I., Onescu, E., Azap, B., Chieffo, N. \& Szitar-Sirbu, M., Seismic vulnerability assessment for the historical areas of the Timisoara city, Romania. Engineering Failure Analysis, 101, pp. 86-112, 2019.

DOI: 10.1016/j.engfailanal.2019.03.013.

[20] Mosoarca, M., Onescu, I., Onescu, E. \& Anastasiadis, A., Seismic vulnerability assessment methodology for historic masonry buildings in the near-field areas. Engineering Failure Analysis, 115, pp. 1-20, 2020.

DOI: 10.1016/j.engfailanal.2020.104662.

[21] Kappes, M.S., Papathoma-Köhle, M. \& Keiler M., Assessing physical vulnerability for multi-hazards using an indicator-based methodology. Applied Geography, 32, pp. 577-590, 2012. DOI: 10.1016/j.apgeog.2011.07.002.

[22] Vargas, Y., Pujades, L., Barbat, A. \& Hurtado, J., Probabilistic assessment of capacity, fragility and seismic damage of reinforced concrete buildings. Revista Internacional de Métodos Numéricos para Cálculo y Diseño en Ingeniería, 29, pp. 63-78, 2013. DOI: 10.1016/j.rimni.2013.04.003.

[23] Maldonado, E., Gómez, I. \& Chio, G., Application of fuzzy sets in the evaluation of seismic vulnerability parameters of masonry buildings. Ing y Desarro, 22, pp. 1-22, 2007.

[24] Calvi, G.M., Pinho, R., Magenes, G., Bommer, J.J., Restrepo-Vélez, L.F. \& Crowley, H., Development of seismic vulnerability assessment methodologies over the past 30 years. ISET Journal of Earthquake Technology, 43, pp. 75-104, 2006.

[25] Municipalidad de Los Olivos, Earthquake Disaster Risk Reduction and Prevention Plan District of Los Olivos, Lima, 2019.

[26] INEI, National Census 2017, 2017. 
PII-24 Earthquake Resistant Engineering Structures XIII

[27] Lázaro, I., Los Olivos: A district on the road to prosperity. Pensam Crítico, 9, pp. 6176, 2014. DOI: 10.15381/pc.v9i0.9023.

[28] Carrillo, J., Evaluation of the seismic vulnerability of structures using a performance design. DYNA, 155, pp. 91-102, 2008.

[29] Chica, A. \& Fuertes, A., Approach to the structural analysis and seismic protection of heritage buildings based on the characterization of their distinctive technical features. Revista Ingeniería de Construcción, 33, pp. 315-326, 2018. DOI: $10.4067 / \mathrm{s} 0718-50732018000300315$.

[30] Iglesias, S., Irigaray, C. \& Chacón, J., Analysis of seismic risk in urban areas using geographic information systems. Application to the City of Granada. Cuad Geográficos, 39, pp. 147-166, 2006.

[31] Maldonado, E., Chio, G., Gómez, I., Seismic vulnerability index for masonry buildings based on expert opinion. Ingeniería y Universidad, 11, pp. 149-168, 2007.

[32] Guzmán, J., Williams, F., Riquer, G., Vargas, A. \& Leyva, R., Soil liquefaction failures induced by the September 7, 2017 earthquake in the City of Coatzacoalcos, Veracruz, Mexico. Revista Ingeniería Sísmica, pp. 82-106, 2020. DOI: 10.18867/ris.102.526.

[33] San Bartolomé, Á. \& Quiun, D., Seismic design of confined masonry buildings. Ciencia, 13, pp. 163-87, 2010.

[34] CISMID, Seismic Microzonation of the District of Los Olivos, 2014.

[35] Birkmann, J., Measuring vulnerability to promote disaster-resilient societies: Conceptual frameworks and definition. 14, 2009. DOI: 10.1002/aehe.3640140303. 